\title{
Leptin promotes proliferation and metastasis of human gallbladder cancer through OB-Rb leptin receptor
}

\author{
HAO ZOU $^{1 *}$, YUNXIA LIU $^{2 *}$, DONG WEI ${ }^{1 *}$, TAO WANG $^{1}, \mathrm{KUN} \mathrm{WANG}^{1}$, SONGQUAN HUANG $^{1}$, \\ LIXIN LIU $^{1}$, YUEHUA LI ${ }^{1}$, JIAYUN GE ${ }^{1}$, XIAO LI ${ }^{1}$, HONG ZHU $^{1}$, LIANMIN WANG ${ }^{1}$, \\ SONGLING ZHAO ${ }^{1}$, XIAOWEN ZHANG ${ }^{1}$ and LIN WANG $^{1}$ \\ ${ }^{1}$ Department of Hepatopancreatobiliary Surgery, The Second Affiliated Hospital \\ of Kunming Medical University, Kunming, Yunnan 650101; ${ }^{2}$ Experiment Teaching Center, \\ Basic Medical School, Kunming Medical University, Kunming, Yunnan 650500, P.R. China
}

Received January 18, 2016; Accepted February 24, 2016

DOI: $10.3892 /$ ijo.2016.3530

\begin{abstract}
Emerging evidence has shown that leptin, an adipocyte-derived cytokine that is closely associated with obesity, play a significant role in carcinogenesis and tumorigenesis. However, its impact on gallbladder cancer (GBC) remains unclear. In this study, we firstly found that leptin and its functional receptor OB-Rb were significantly co-expressed in human GBC tissues and cell lines, the content of which were higher than those in normal human gallbladder tissues. Treatment with leptin promoted the proliferation, migration and invasion of GBC cells, which were attenuated by OB-Rb shRNA. Blocking in the G2/M period of cell cycle, increasing of MMP3 and MMP9, increasing of VEGF-C/D, activation of SOCS3/JAK2/p-STAT3 pathway was demonstrated after treatment with leptin. All of these positive responses were attenuated by OB-Rb receptor shRNA. Taken together, our findings suggest that leptin promoted the proliferation, migration and invasion of GBC cells by increasing OB-Rb expression through the SOCS3/JAK2/p-STAT3 signal pathway. Targeting the leptin/OB-Rb axis could be an attractive therapeutic strategy for treatment of GBC.
\end{abstract}

\section{Introduction}

Gallbladder cancer (GBC) is a rare but highly aggressive malignancy. The lack of severe symptoms makes the diagnosis very difficult (1). Even though there are some therapies such as

Correspondence to: Dr Xiaowen Zhang or Dr Lin Wang, Department of Hepatopancreatobiliary Surgery, The Second Affiliated Hospital of Kunming Medical University, 374 Dianmian Road, Kunming, Yunnan 650101, P.R. China

E-mail: zhangxiaowenlu@hotmail.com

E-mail: wanglinghjt@163.com

*Contributed equally

Key words: leptin, gallbladder cancer, proliferation, metastasis, $\mathrm{OB}-\mathrm{Rb}$ cholecystectomy or radical resection, chemotherapy, or radiotherapy $(2,3)$, they are not as effective as expected. The 5-year survival rate is extremely low (4). So far there is no systemic therapy with a satisfactory outcomes. Thus, studying novel signal molecules involved in GBC margin and metastasis may provide new effective therapeutic strategies.

Leptin, the product of the OB gene, is a $16 \mathrm{kDa}$ nonglycosylated peptide hormone which is synthesized almost exclusively by adipocytes that regulates appetite and energy expenditure at the hypothalamic level $(5,6)$. In recent years, accumulating evidence suggests that leptin plays an important role in tumorigenesis, angiogenesis and metastasis of many cancers, including breast (7), pancreatic (8), and stomach cancer (9). Previous studies have shown that leptin could activate Janus kinase 2 (JAK2) when leptin was bound to one form of the receptor, OB-Rb. Then JAK2 initiated downstream signaling including members of the signal transducers and activators of transcription (STAT) family of transcription factors (10). However, the expression of leptin and $\mathrm{OB}-\mathrm{Rb}$ in GBCs has not been fully investigated, and the precise role of leptin in the development and promotion of GBC remains unknown.

In this study, we investigated the clinical implications of leptin and $\mathrm{OB}-\mathrm{Rb}$ in $\mathrm{GBC}$ patients. Moreover, we explored the role of leptin and one form of its receptor OB-Rb in GBC cells through in vitro and in vivo studies. SOCS3/JAK2/p-STAT3 signaling pathways were also assessed and these pathways may be involved in cell migration and metastasis by leptin.

\section{Materials and methods}

Immunohistochemistry and evaluation. Forty paraffinembedded specimens of normal gallbladder tissues and 40 specimens of gallbladder cancer (GBC) tissues were collected from January 1, 2005 to June 30, 2010 at Department of Hepatopancreatobiliary Surgery, the Second Affiliated Hospital of Kunming Medical University, Kunming, China. No patients had received chemotherapy or radiotherapy before biopsy. The prior patient's consents and approval from the Institutional Research Ethics Committee were obtained. Rabbit anti-human polyclonal leptin and OB-Rb antibody 
(Sigma, St. Louis, MO, USA) was used for immunohistochemistry assay, which was performed following the protocol of Universal SP kit (MXB Biotechnology, Fujian, China). Positive staining of leptin protein is brown in the cytoplasm, partly in the nucleus, and positive staining of OB-Rb protein is brown in the cytomembrane. The human GBC tissue sections were blindly examined and scored concurrently by two observers. The intensity of the immunostaining was scored as 0 (negative), 1 (weak), 2 (moderate), or 3 (strong). Four visual fields were selected randomly under high power lens (x400). The number of positive cells was counted and the average positive rate was calculated. The percentage of positive tumor cells was scored as '+' (<25\%), '++' (26-50\%), '+++' (51-75\%), or '++++', (76-100\%), and that without any positive cells scored as '-'.

Cell culture. The human GBC cell sublines (GBC-SD) were obtained from the Type Culture Collection of the Chinese Academy of Sciences (Shanghai, China). The cells were cultured in Dulbecco's modified Eagle's medium/ $\alpha$-modified Eagle medium (DMEM) (Gibco Life Technology, Gaithersburg, MD, USA) supplemented with $10 \%$ fetal bovine serum (FBS) (Gibco Life Technology) and maintained at $37^{\circ} \mathrm{C}$ in a humidified atmosphere of $5 \% \mathrm{CO}_{2}$.

shRNA synthesis and transfection. Four different template oligonucleotides targeting OB-Rb (Table II) were synthesized by Ribobio Inc. (Guangzhou, Guangdong, China), and were annealed and ligated into pGPH1/GFP/Neo plasmid. The shRNAs inserted vectors were named as pGPH-GFP-s1, pGPH-GFP-s2, pGPH-GFP-s3, pGPH-GFP-s4 and pGPHGFP-NC, respectively.

Transfection of shRNAs was performed using Lipofectamine 2000 reagent (Invitrogen Co., Carlsbad, CA) according to the manufacturer's instructions. Briefly, GBC-SD cells were applied for OB-Rb silence, which were cultured in 6 -well plates at a density of $5 \times 10^{4}$ cells/well. Then GBC-SD cells were subject to shR-OB-Rb and shR-Con treatment for 24,48 and $96 \mathrm{~h}$. To evaluate the infection efficiency, cells were observed under a fluorescence microscope and the percentage of GFP-positive cells was counted.

Quantitative real-time PCR analysis. Total RNA from GBC-SD cells was extracted using the TRIzol reagent (Invitrogen). Then, $2 \mu \mathrm{g}$ of total RNA was subjected to reverse transcription for cDNA synthesis by using MMLV (MBI Fermentas, Euromedex, Souffelweyersheim, France). Real-time PCR was performed with the manufacturer's (Kapa Biosystem, Hercules, CA, USA) instructions. The primer sequences listed below were used. A mathematical model, $2^{-\Delta \Delta C T}$ method, was used for relative quantification in real-time PCR (11). GAPDH was used as internal control gene to normalize the variability at mRNA expression levels.

Western blot analysis. The GBC-SD cell pellet was washed twice with ice-cold phosphate buffered saline (PBS) and lysed with lysis buffer (Beyotime Institute of Biotechnology, Jiangsu, China). Protein (30 mg) was loaded and separated in $12 \%$ sodium dodecyl sulfate polyacrylamide gel electrophoresis (SDS-PAGE) gel and transferred to polyvinylidene difluoride membranes (Millipore, Bedford, MA, USA).
The following antibodies were used to probe the alterations of protein: JAK2 (Abcam, Cambridge, UK), SOCS3 (Abcam), STAT3 and p-STAT3 (Cell Signaling Technology, Inc., Danvers, MA, USA), MMP-3 and MMP-9 (Santa Cruz Biotechnology, Santa Cruz, CA, USA), VEGF-C/D (Santa Cruz Biotechnology). GAPDH (Santa Cruz Biotechnology) was used as loading control. Signal was detected by enhanced chemiluminescence techniques (Pierce Thermo Scientific, Rockford, IL, USA).

Cell proliferation assay. Cells $\left(2 \times 10^{4}\right)$ per well were seeded into 96-well plate and incubated overnight. Then the medium was removed. Medium (100 $\mu \mathrm{l})$ with the final concentration of $100 \mathrm{nM}$ OB-Rb shRNA was added to each well with or without leptin $(250 \mathrm{ng} / \mathrm{ml})$. Scramble shRNA or untreated cells were used as the control group. All groups were in triplicate. After 24, 48, and $72 \mathrm{~h}$ transfection, cell proliferation was determined by 3-(4,5-dimethylthiazol-2-yl) -2,5-diphenyl tetrazolium bromide (MTT) assay (Beyotime Institute of Biotechnology).

Flow cytometry analysis. Cells $\left(2 \times 10^{5}\right)$ were seeded in 6-well plates and incubated overnight to $50-60 \%$ confluence. OB-Rb shRNA was added into the medium at a final concentration of $100 \mathrm{nM}$ with or without leptin $(250 \mathrm{ng} / \mathrm{ml})$. Scramble shRNA or untreated cells were used as the control group. The cells were incubated with leptin for $24 \mathrm{~h}$, then treated into single cell suspension with cold PBS. The experiment was performed following manufacturer's protocol of Annexin V-FITC Apoptosis and Cells cycle Detection kit (Beyotime Biotechnology, Jiangsu, China). Then, rates of apoptosis were analyzed with FACScan system (BD Biosciences, Franklin Lakes, NJ, USA). Each experiment was performed in triplicate, independently.

Cell migration and invasion assay. Transwell chambers and Matrigel Invasion Chambers $(8 \mu \mathrm{m}$ pore size, Corning Inc., Corning, NY, USA) were used for cell migration and invasion assay, respectively. GBC-SD cells transfected with OB-Rb shRNA or scramble shRNA were treated with or without leptin ( $250 \mathrm{ng} / \mathrm{ml}$ ). After $24 \mathrm{~h}$, cells were detached. Then $500 \mu \mathrm{l}$ medium with $20 \%$ FBS was added into each lower chamber which was incubated at $37^{\circ} \mathrm{C}$. Incubation periods were $2 \mathrm{~h}$ for migration, and $4 \mathrm{~h}$ for invasion. Then, the surface of the upper chamber was swabbed with cotton-tipped applicators to remove the cells that did not migrate. The lower membrane surface was fixed in methanol and stained by crystal violet. Migrating cells were counted using light microscopy (five random 100x fields per well) or a spectrophotometer. Results were calculated from three independent experiments.

Immunofluorescence. shRNA-transfected cells $\left(2 \times 10^{5}\right)$ and untreated cells were all seeded on coverslips. Cells were cultured in a 6-well plate and incubated with leptin for $24 \mathrm{~h}$, then rinsed twice in PBS and fixed with methanol at $-20^{\circ} \mathrm{C}$ for $20 \mathrm{~min}$. Following fixation, the coverslips were directly washed in PBS for 5 min, followed by incubation with PBS, $0.2 \%$ Triton $\mathrm{X}-100$ and $5 \%$ bovine serum albumin for $20 \mathrm{~min}$ at room temperature. Following rinsing with $\mathrm{PBS}$, the cells were incubated with primary antibody at $4^{\circ} \mathrm{C}$ in a humidity 
Table I. Clinical characteristics of 40 gallbladder carcinoma (GBC) patients and leptin and OB-Rb expression.

\begin{tabular}{|c|c|c|c|c|c|c|}
\hline \multirow[b]{2}{*}{ Characteristics } & \multicolumn{2}{|c|}{ Leptin } & \multirow[b]{2}{*}{ P-value } & \multicolumn{2}{|c|}{$\mathrm{OB}-\mathrm{Rb}$} & \multirow[b]{2}{*}{ P-value } \\
\hline & $\begin{array}{c}\text { Low } \\
(\mathrm{n}=15)\end{array}$ & $\begin{array}{c}\text { High } \\
(\mathrm{n}=25)\end{array}$ & & $\begin{array}{c}\text { Low } \\
(\mathrm{n}=17)\end{array}$ & $\begin{array}{l}\text { High } \\
(n=23)\end{array}$ & \\
\hline \multicolumn{7}{|l|}{ Age } \\
\hline$\geq 60$ & 8 & 11 & 0.567 & 11 & 8 & 0.061 \\
\hline$<60$ & 7 & 14 & & 6 & 15 & \\
\hline \multicolumn{7}{|l|}{ Gender } \\
\hline Male & 3 & 9 & 0.285 & 5 & 7 & 0.994 \\
\hline Female & 12 & 16 & & 12 & 16 & \\
\hline \multicolumn{7}{|l|}{$\mathrm{BMI}, \mathrm{kg} / \mathrm{m}^{2}$} \\
\hline$<30$ & 12 & 1 & $<0.001$ & 13 & 0 & $<0.001$ \\
\hline$\geq 30$ & 3 & 24 & & 4 & 23 & \\
\hline \multicolumn{7}{|l|}{$\mathrm{CA} 199, \mathrm{U} / \mathrm{ml}$} \\
\hline$<35$ & 9 & 1 & $<0.001$ & 10 & 0 & $<0.001$ \\
\hline$\geq 35$ & 6 & 24 & & 7 & 23 & \\
\hline \multicolumn{7}{|c|}{ T classification (1) } \\
\hline $\mathrm{T} 1 \mathrm{~b} / \mathrm{T} 2$ & 14 & 15 & 0.030 & 16 & 13 & 0.012 \\
\hline $\mathrm{T} 3$ & 1 & 10 & & 1 & 10 & \\
\hline \multicolumn{7}{|c|}{$\mathrm{N}$ classification (1) } \\
\hline No & 15 & 14 & 0.003 & 17 & 12 & 0.001 \\
\hline N1 & 0 & 11 & & 0 & 11 & \\
\hline \multicolumn{7}{|c|}{ Tumor differentiation } \\
\hline $\mathrm{I} / \mathrm{II}$ & 13 & 13 & 0.026 & 13 & 13 & 0.191 \\
\hline III/IV & 2 & 12 & & 4 & 10 & \\
\hline \multicolumn{7}{|l|}{$\operatorname{AJCC}(1)$} \\
\hline I & 14 & 10 & 0.001 & 16 & 8 & $<0.001$ \\
\hline II & 1 & 15 & & 1 & 15 & \\
\hline
\end{tabular}

$\mathrm{P}<0.05$ was considered statistically significant. Pearson's Chi-square test and Fisher exact test (when $1<\mathrm{T}<5$ ) were used.

box. Primary antibodies included mouse anti-JAK2 (1:200; Abcam), rabbit anti-STAT3 or p-STAT3 (1:200; CST) and rabbit polyclonal to SOCS3 (1:200; Abcam). Coverslips were subsequently washed 3 times with cold PBS and incubated with the corresponding secondary antibodies (diluted to 1:500, Santa Cruz Biotechnology) for $2 \mathrm{~h}$ at room temperature in the dark, humid box. DAPI staining was then performed to identify the nuclei.

Gelatin zymography assay. Cells $\left(2 \times 10^{5}\right)$ transfected with OB-Rb shRNA or scramble shRNA were seeded in a 6 -well plates and incubated for $6 \mathrm{~h}$. Then leptin $(250 \mathrm{ng} / \mathrm{ml})$ was added and the cells incubated for another $24 \mathrm{~h}$. After each treatment, the cells were washed twice with serum-free medium, and used for a zymogram according to the protocol of Zymography kit (Genmed, Shanghai, China).

Enzyme-linked immunosorbent assay (ELISA). VEGF-C and VEGF-D levels were detected using the ELISA kit according to the manufacturer's manual (Keygentec,
Shanghai, China). Colorimetric measurement was recorded as OD 450 readings.

Xenograft model assay. All animal procedures were previously approved by the Kunming Medical University ethics committee. Female BALB/c nu/nu mice (4-5 weeks old, 15-18 g), from Vital River Laboratory Animal Technology Co., Ltd. (Peking, China), were randomly assigned into five groups as described above: control, shR-NC, leptin (1 mg/kg), shR-OB-Rb, and shR$\mathrm{OB}-\mathrm{Rb}+$ Leptin $(1 \mathrm{mg} / \mathrm{kg})$, groups. Approximately $5 \times 10^{6}$ cells were suspended in $0.1 \mathrm{ml}$ PBS and injected subcutaneously into each mouse. The tumors were monitored every 5 days beginning at day 5 by measuring two perpendicular diameters with a caliper. The mice were sacrificed on the 30th day after injection. The tumors were dissected and weighed.

Statistical analysis. Statistical analysis was performed with SPSS software (17.0; SPSS, Inc., Chicago, IL, USA). Values are expressed as mean \pm standard deviation (SD). The Student's t-test was used for comparisons between groups. 
A

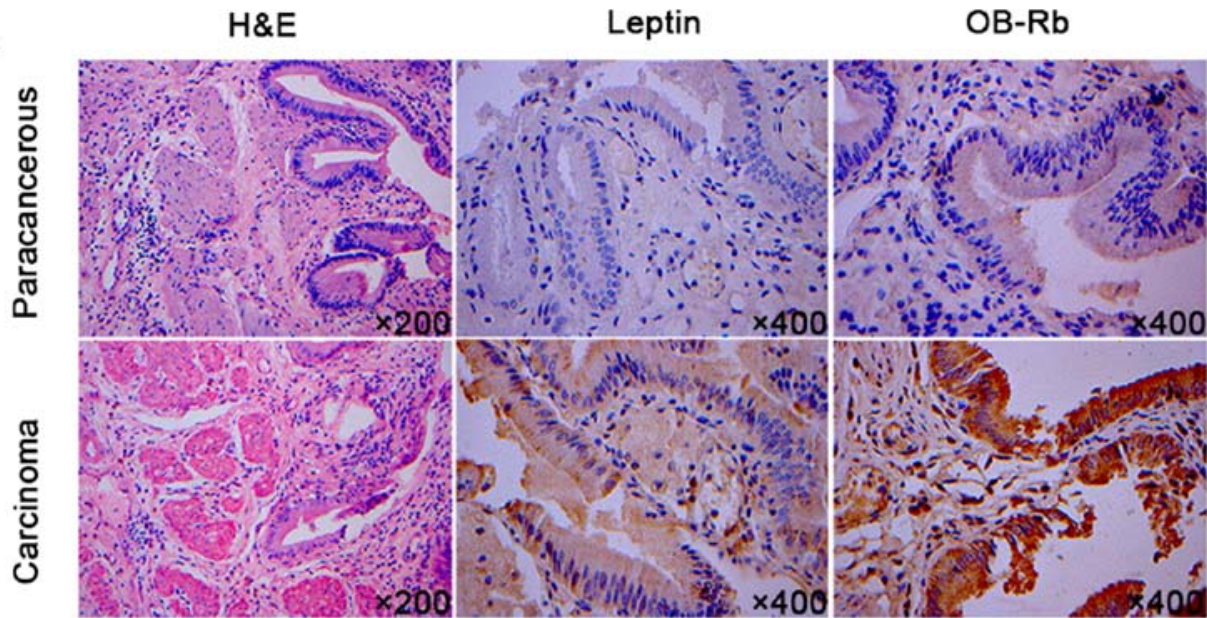

B
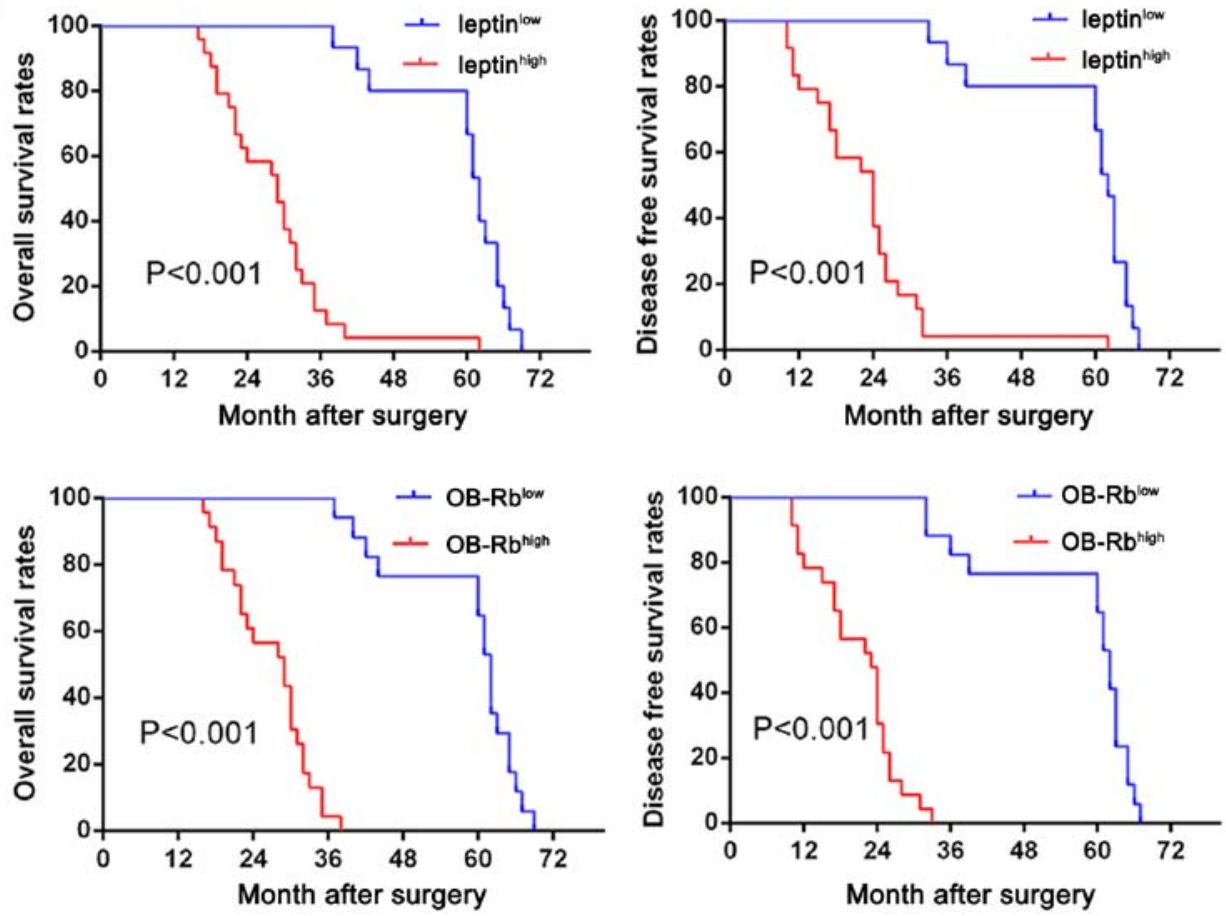

Figure 1. Leptin and OB-Rb expression in gallbladder carcinoma (GBC) tissues and their prognostic significance in GBC patients. (A) Immunohistochemistry staining of leptin and OB-Rb in human gallbladder tissues. GBC tissues exhibited significantly higher expression of leptin and OB-Rb. (B) High expression of leptin and OB-Rb was associated with a poor prognosis in 40 GBC patients. Kaplan-Meier plots show disease-free survival (DFS) and overall survival (OS) curves according to leptin and OB-Rb expression levels (low, blue line; high, red line) in the primary tumor (P<0.001, log-rank test).

Categorical data were analyzed by the chi-square or Fisher's exact tests. Correlation analysis was performed between leptin and $\mathrm{OB}-\mathrm{Rb}$. Cumulative recurrence and survival rates were analyzed using Kaplan-Meier's method and the log-rank test. Cox's proportional hazards regression model was used to analyze independent prognostic factors. Statistical significance was defined as P-value $<0.05$.

\section{Results}

Expression levels of leptin and $O B-R b$ in $G B C$ tissues. To evaluate the possible roles of leptin in GBC, we investigated the expression levels of leptin and $\mathrm{OB}-\mathrm{Rb}$ in human normal gallbladder and GBC tissues by immunohistochemistry. Compared to normal gallbladder tissues, expression levels of leptin were significantly upregulated in GBC tissues
$(\mathrm{P}=0.000)$. Moreover, OB-Rb density was significantly higher in GBC tissues than in normal gallbladder tissues $(\mathrm{P}=0.001)$ (Fig. 1A). In addition, a scatter plot of leptin and $\mathrm{OB}-\mathrm{Rb}$ expression revealed a significantly positive correlation between leptin and OB-Rb levels in cancerous tissues $(\mathrm{r}=0.797, \mathrm{P}=0.000)$. The characteristics of the study participants including age, gender, BMI, T classification, $\mathrm{N}$ classification, Tumor differentiation, AJCC stage are shown in Table I. Results demonstrated that GBC patients with leptin ${ }^{\text {high }}$ had high BMI $(\mathrm{P}<0.001)$, elevated CA199 $(\mathrm{P}<0.001)$, high $\mathrm{T}(\mathrm{P}=0.030), \mathrm{N}(\mathrm{P}=0.003)$ classification and AJCC stage $(\mathrm{P}=0.001)$, poor differentiation $(\mathrm{P}=0.026)$. Moreover, $\mathrm{GBC}$ patients with $\mathrm{OB}-\mathrm{Rb}^{\text {high }}$ had high $\mathrm{BMI}(\mathrm{P}<0.001)$, elevated CA199 $(\mathrm{P}<0.001)$, high T $(\mathrm{P}=0.012), \mathrm{N}(\mathrm{P}=0.001)$ classification and AJCC stage $(\mathrm{P}<0.001)$, poor differentiation $(\mathrm{P}=0.026)$. We then analyzed the prognostic implication of leptin and OB-Rb 

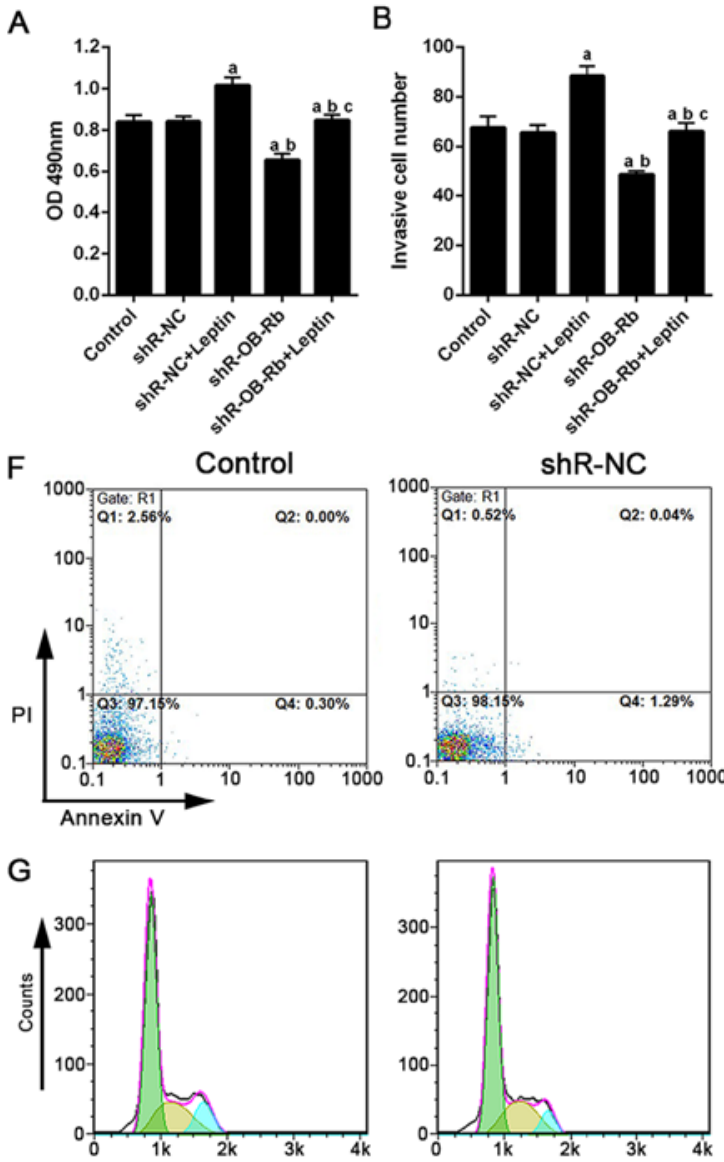

$\mathrm{H}$
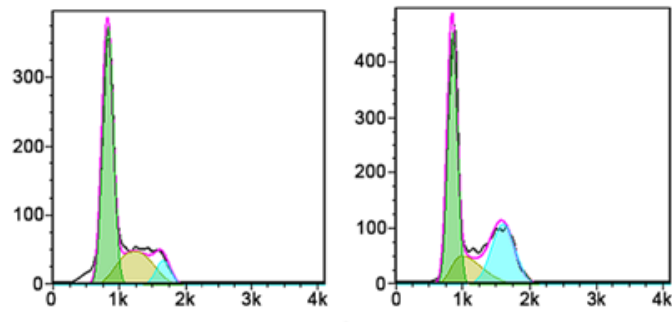

I
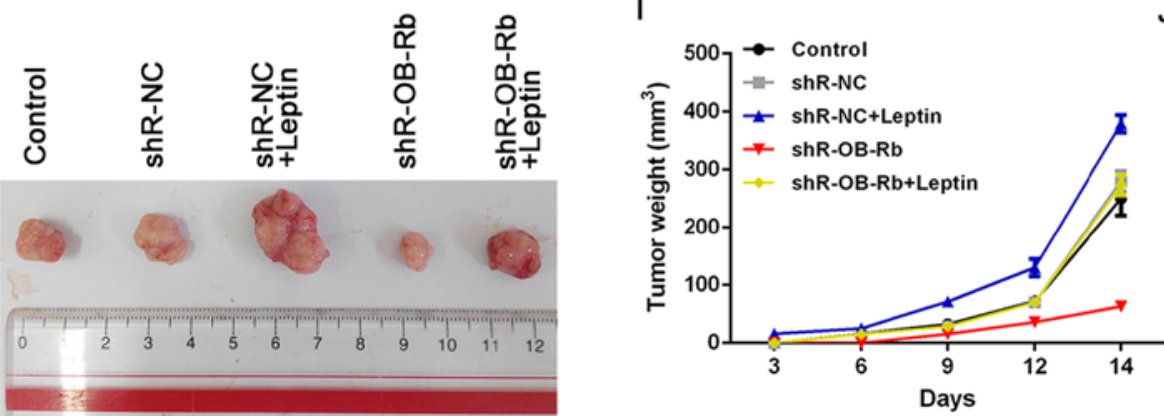
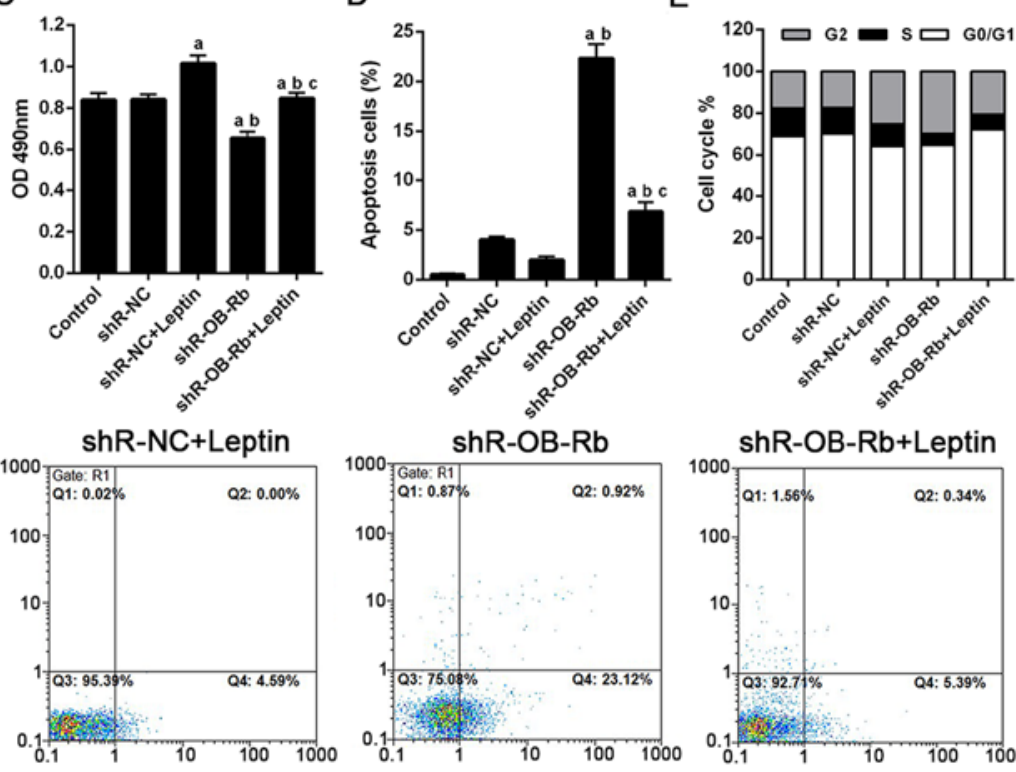

shR-OB-Rb+Leptin

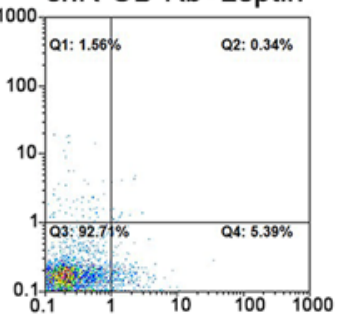

Figure 2. Effects of leptin and OB-Rb in human gallbladder carcinoma cells in vitro and in vivo. (A) Growth of GBC-SD cells was analyzed by MMT after $24 \mathrm{~h}$ of treatment with $40 \mathrm{ng} / \mathrm{ml}$ leptin with control shRNA or OB-Rb shRNA. (B) Migration and (C) invasion of GBC-SD cells were both analyzed by Transwell (D and F) Cell apoptosis and (E and G) cell cycle were analyzed by flow cytometry after $24 \mathrm{~h}$ of incubation with $40 \mathrm{ng} / \mathrm{ml}$ leptin with control shRNA or OB-Rb shRNA. GBC-SD cells were stably infected with shR-NC or shR-OB-Rb and injected into BALB/c-nude mice. Established s.c. xenografts were treated with $1 \mathrm{mg} / \mathrm{kg}$ leptin or control saline on two consecutive days per week for 4 weeks. (H) Representative images of xenografts from different groups. (I and J) Tumor volume and tumor weight were determined. These data represent the mean \pm SD of three independent experiments. Statistical analysis used two-tailed Student's t-test $\left({ }^{a} \mathrm{P}<0.05\right.$ vs. shR-NC group; ${ }^{\mathrm{b}} \mathrm{P}<0.05$ vs. shR-NC + Leptin group; ${ }^{\mathrm{c}} \mathrm{P}<0.05$ vs. shR-OB-Rb group).

expression. Importantly, we found that patients with leptin ${ }^{\text {high }}$ and $\mathrm{OB}-\mathrm{Rb}^{\text {high }}$ expression had significantly worse prognosis than those with leptin ${ }^{\text {low }}$ and OB-Rb ${ }^{\text {low }}$ expression (Fig. 1B). Multivariate analysis identified leptin and OB-Rb expression as an independent predictor for disease-free survival and overall survival (OS; Table II). These results indicate that leptin and $\mathrm{OB}-\mathrm{Rb}$ is likely involved in tumorigenesis and progression of GBC.

Involvement of $O B-R b$ receptor in leptin-mediated growth, migration and invasion of $G B C-S D$ cells. Leptin exhibits its effects on cancer through interaction with specific leptin receptors (OB-Rb and $\mathrm{OB}-\mathrm{Rs})$ (12). In this study, we examined the effect of leptin on GBC-SD cell growth, migration and invasion. The result from MTT assay showed leptin $(40 \mathrm{ng} / \mathrm{ml})$ significantly increased the proliferation of GBC-SD cells after 24-h incubation compared with basal values, which were significantly inhibited by shR-OB-Rb transfection (Fig. 2A).

Leptin was able to promote GBC-SD cell migration, which was significantly suppressed in GBC-SD cell transfected with OB-Rb shRNA at $24 \mathrm{~h}$ compared with the control group as shown in Fig. 2B. Transwell matrix penetration assay showed that leptin treatment increased the mean of GBC-SD cell 
A

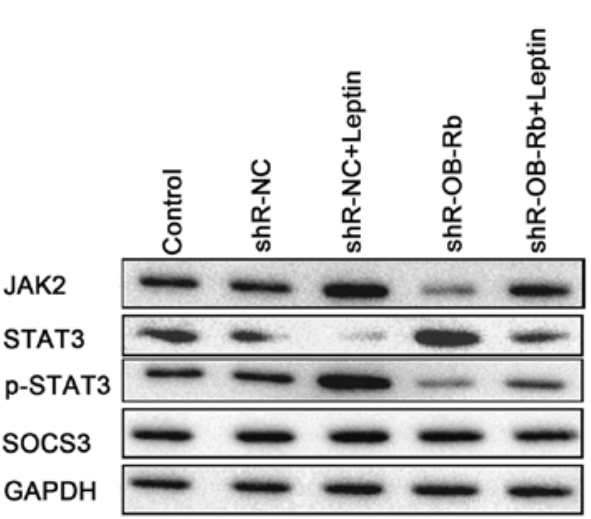

B

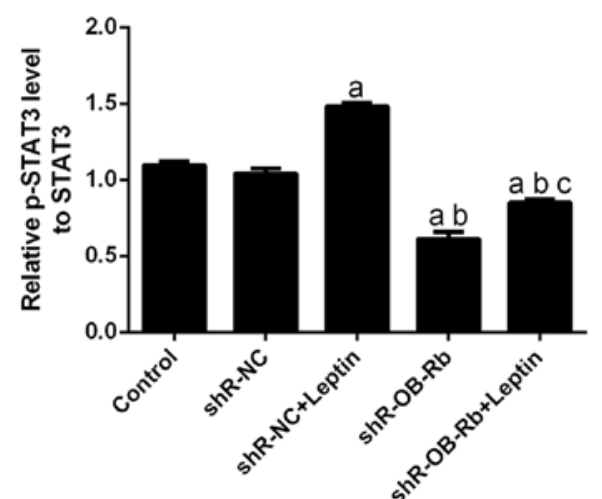

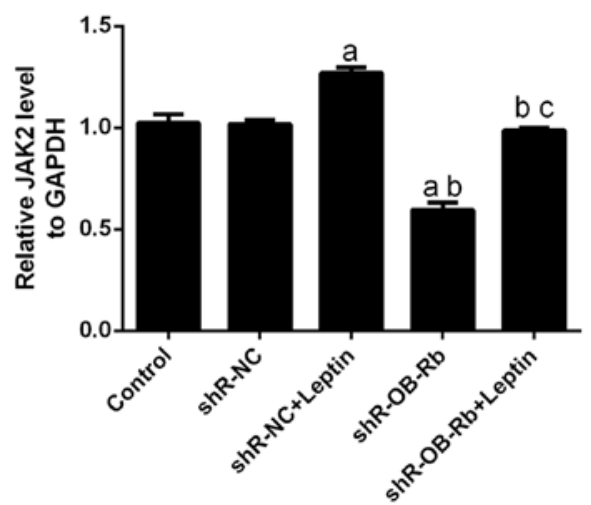

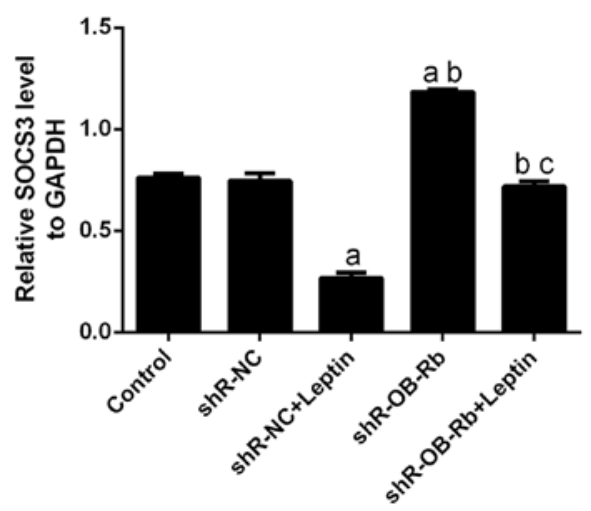

C

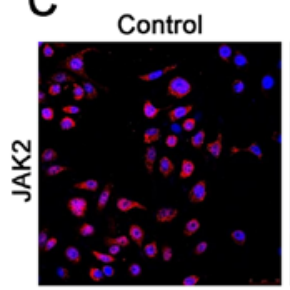

shR-NC
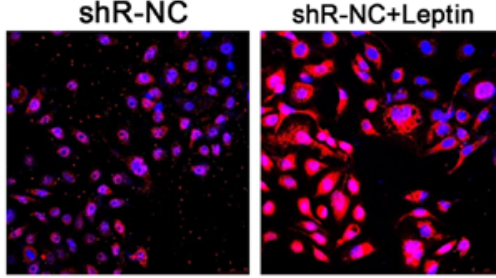

shR-OB-Rb

shR-OB-Rb+Leptin
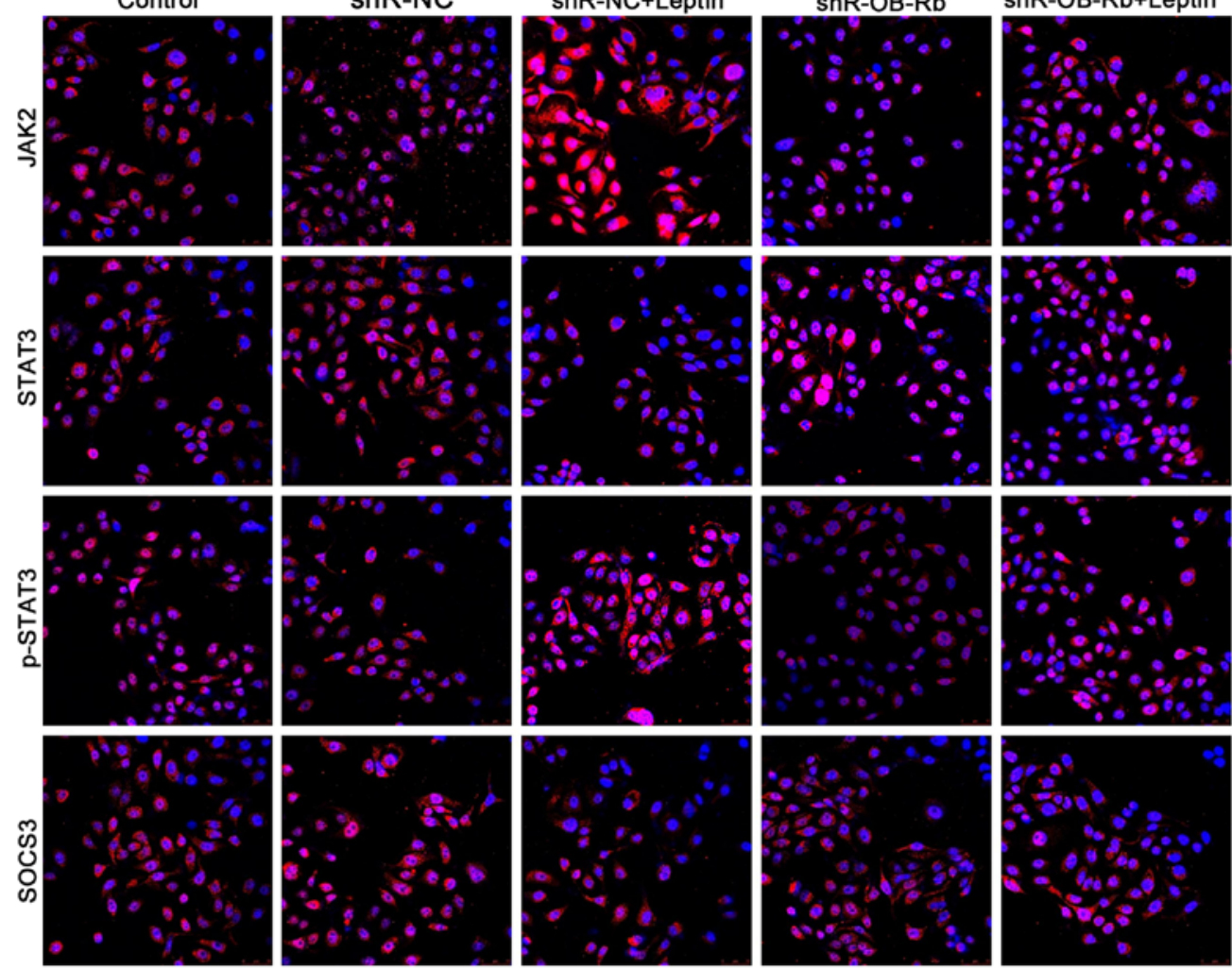

Figure 3. Leptin activates the JAK2/STAT3/SOCS3 signal pathway. (A and B) Western blot analysis of the protein expression of JAK2, STAT3, phosph-STAT3 and SOCS3 in leptin or shR-OB-Rb-transfected GBC-SD cells. (C) Immunofluorescence analysis of these protein in leptin or shR-OB-Rb-transfected GBC-SD cells. These data represent the mean $\pm \mathrm{SD}$ of three independent experiments. Statistical analysis used two-tailed Student's t-test $\left({ }^{a} \mathrm{P}<0.05 \mathrm{vs}\right.$. shR-NC group; ${ }^{\mathrm{b}} \mathrm{P}<0.05$ vs. shR-NC + Leptin group; ${ }^{\mathrm{c}} \mathrm{P}<0.05$ vs. shR-OB-Rb group).

invasive number, which could be repressed by transfection with OB-Rb shRNA (Fig. 2C). Flow cytometry was used to analyze cell apoptosis in GBC-SD treated with leptin or
OB-Rb shRNA for 24 h. As shown in Fig. 2D-G, leptin treatment or OB-Rb knockdown significantly induced G2/M-phase cell cycle arrest, and decreased cells number of G0/G1 and 
Table II. Uni- and multivariate analyses of factors associated with survival.

\begin{tabular}{|c|c|c|c|c|c|c|c|c|}
\hline \multirow[b]{3}{*}{ Factor } & \multicolumn{4}{|c|}{ OS } & \multicolumn{4}{|c|}{ DFS } \\
\hline & \multirow{2}{*}{$\begin{array}{l}\text { Univariate, } \\
\text { P-value }\end{array}$} & \multicolumn{3}{|c|}{ Multivariate } & \multirow{2}{*}{$\begin{array}{c}\text { Univariate, } \\
\text { P-value }\end{array}$} & \multicolumn{3}{|c|}{ Multivariate } \\
\hline & & HR & $95 \% \mathrm{CI}$ & $\mathrm{P}$-value & & HR & $95 \% \mathrm{CI}$ & P-value \\
\hline Gender (male vs. female) & 0.117 & & & NA & 0.328 & & & NA \\
\hline Age, years ( $\geq 60$ vs. $<60)$ & 0.056 & & & NA & 0.070 & & & NA \\
\hline BMI, $\mathrm{kg} / \mathrm{m}^{2}$ ( $\geq 30$ vs. $\left.<30\right)$ & 0.584 & & & NA & 0.326 & & & NA \\
\hline CA199, U/ml ( $\geq 35$ vs. $<35)$ & 0.002 & 3.532 & $1.485-13.406$ & 0.012 & 0.004 & 3.876 & $1.514-12.711$ & 0.027 \\
\hline T classification (T1 vs. T2) & 0.091 & & & NA & 0.242 & & & NA \\
\hline $\mathrm{N}$ classification (N0 vs. $\mathrm{N} 1$ ) & 0.093 & & & NA & 0.167 & & & NA \\
\hline Tumor differentiation (I/II vs. III/IV) & 0.782 & & & NA & 0.765 & & & NA \\
\hline AJCC (I vs. II) & 0.575 & & & NA & 0.648 & & & NA \\
\hline Leptin expression (low vs. high) & 0.028 & 2.271 & $1.865-18.615$ & 0.001 & 0.044 & 2.874 & $1.196-19.682$ & 0.003 \\
\hline OB-Rb expression (low vs. high) & 0.016 & 3.461 & $2.043-18.292$ & 0.001 & 0.020 & 2.931 & $1.970-11.438$ & 0.001 \\
\hline
\end{tabular}

Cox's proportional hazards regression model. OS, overall survival; DFS, disease-free survival; HR, hazard ratio; 95\% CI, 95\% confidence interval; NA, not adopted.

S-phase. OB-Rb knockdown significantly induced apoptosis in GBC-SD cell line, compared with the other groups $(\mathrm{P}<0.05)$.

Leptin promoting growth and metastasis were retarded by $O B-R b R N A i$. In vivo, the volumes and weight of xenograft tumors removed from nude mice which were injected with leptin and shR-NC were both higher than the other groups. In addition, they were retarded apparently in Leptin + shR$\mathrm{OB}-\mathrm{Rb}$ group after 30 days. As shown in Fig. 2H-J, the growth of xenograft tumors in shR-OB-Rb group obviously less than the other groups.

Signaling pathways of JAK2/STAT3/SOCS3 were involved in leptin stimulation. The leptin action was by signaling via JAK2 and phosphorylation of STAT3 or other pathways such as SOCS3 $(13,14)$. In GBC-SD cells, we found that leptin increased JAK2 expression levels and STAT3 phosphorylation, and decreased SOCS3 expression levels. Such an effect was blocked by shR-OB-Rb treatment (Fig. 3A and B). The immunofluorescence experiments also confirmed similar results (Fig. 3C). These results indicate that the JAK2/STAT3/ SOCS3 pathway is involved in leptin-induced migration of human GBC cells.

shR-OB-Rb downregulated MMP-3/9 activity and expression of VEGF-C/D increased by leptin. Numerous studies have mechanistically associated the invasive and metastasis ability of cancer cells with expression of VEGF factors (15) and activation of MMP family (16). To understand the mechanism by which leptin promoted the invasiveness and migration of GBC-SD cells, we investigated the expression of VEGF-C/D and activity of MMP-9 in GBC-SD cells treated with leptin and/or transfected with shR-OB-Rb. As shown in Fig. 4A, gelatin zymography assay results show leptin increases MMP-3 and MMP-9 activity in GBC-SD cells, which are attenuated by transfecting shR-OB-Rb. ELISA also confirmed similar result in expression of VEGF-C and VEGF-D (Fig. 4B). Then we detected activity of MMP-3/9 and expression of VEGF-C/D in vivo, which were confirmed by western blot (Fig. 4C and D) and immunofluorescence (Fig. 4E-J) analysis. Taken together, these data suggested that leptin upregulated VEGF-C/D levels and activated MMP-3/9 in vivo and in vitro.

\section{Discussion}

Our results indicate that leptin and $\mathrm{OB}-\mathrm{Rb}$ are expressed at a high level in GBC patients, compare with normal gallbladder tissue. In addition, a high level of leptin and $\mathrm{OB}-\mathrm{Rb}$ is a poor prognostic marker for GBC patient. Furthermore, this study shows for the first time that leptin and OB-Rb mediates migration of human gallbladder cancer (GBC) cells. We show that in vitro: i) leptin stimulates growth and migration of GBC-SD cells; ii) the enhancement of GBC-SD cell growth by leptin is associated with $\mathrm{G} 2 / \mathrm{M}$ cell cycle arrest, iii) activity of MMP-3/9 and expression VEGF-C/D is determined. iv) JAK2/STAT3/SOCS3 pathway is involved in this process. Moreover, in vivo v) genetic ablation of leptinmediated signaling enhanced cancer growth in an animal model of GBC. Moreover, these effect could all be attenuated by $\mathrm{OB}-\mathrm{Rb}$ receptor shRNA.

Several studies have shown strong epidemiologic evidence suggesting the existence of a close link between obesity, a clinical condition characterized by high levels of circulating leptin (17) and a multitude of cancers, such as prostate (18), mammary (19), endometrial (20), hepatocellular (21), colon (22), pancreatic (23), adenocarcinoma of esophagus (24), and cholangiocarcinoma (25). In this study, consistent data show that leptin enhanced progression of GBC. Leptin is usually related to binding with its receptor OB-Rb, which belongs to the cytokine receptor superfamily (26). It has been reported that human cancer cells expressed OB-Rb and other OB-Rs leptin receptors (27). However, the role of OB-Rb in human GBC is 
A

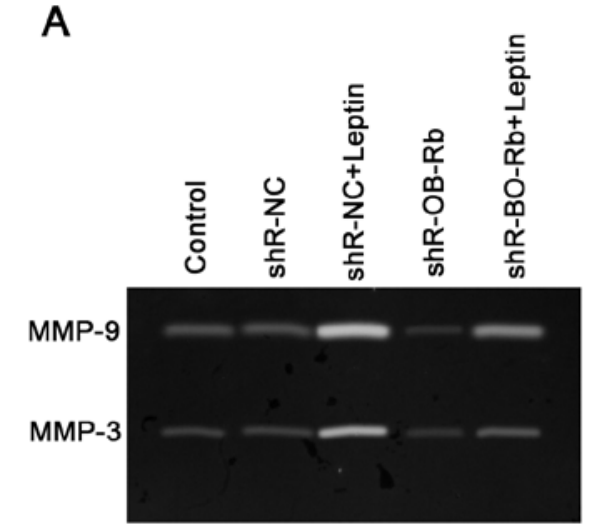

B
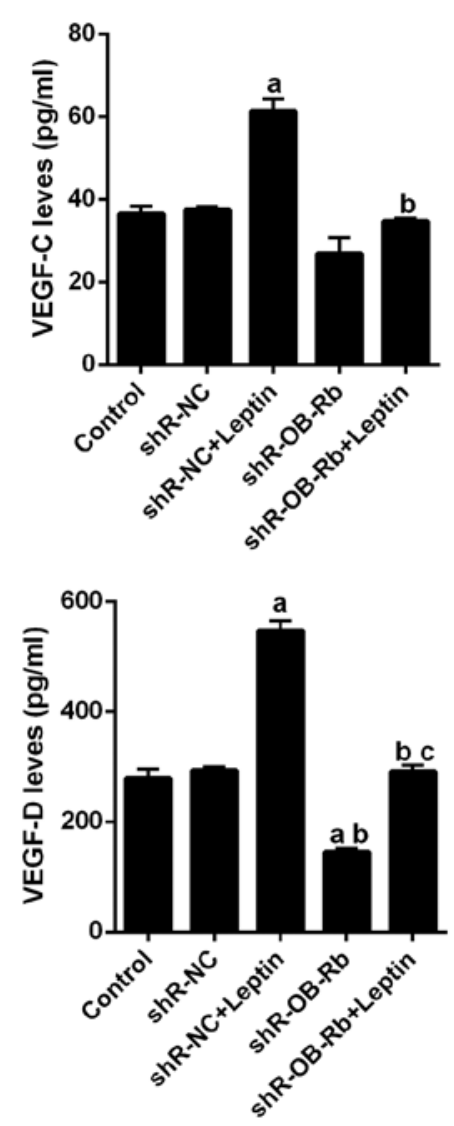

C

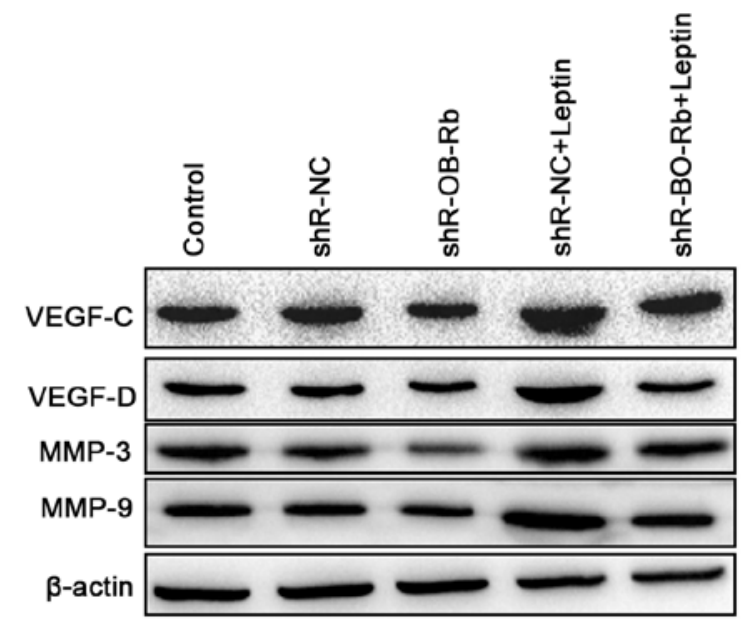

D
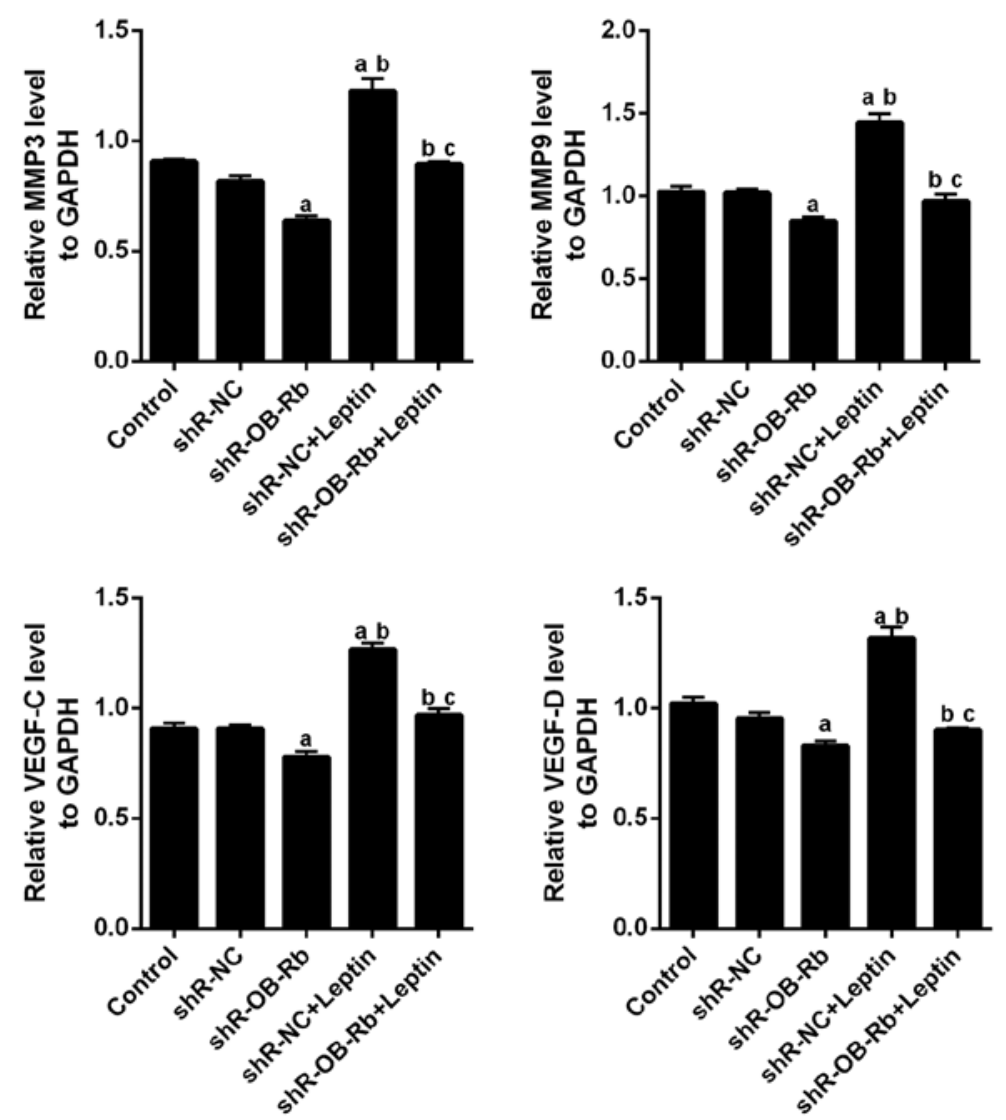

Figure 4. Leptin or OB-Rb regulates MMP3/9 and VEGF-C/D. (A) Gelatin zymography assay shown leptin upregulate expression of MMP3/9 and shR-OB-Rb reverse them. (B) Letpin promote secretion of VEGF-C/D in GBC-SD cells by ELISA assay. The protein expression of MMP3/9 and VEGF-C/D were also confirmed by western blot (C and D) analysis and in letpin or shR-OB-Rb-transfected GBC-SD cells. These data represent the mean \pm SD of three independent experiments. Statistical analysis used two-tailed Student's t-test $\left({ }^{a} \mathrm{P}<0.05\right.$ vs. shR-NC group; ${ }^{b} \mathrm{P}<0.05$ vs. shR-NC + Leptin group; ${ }^{\mathrm{C}} \mathrm{P}<0.05$ vs. shR-OB-Rb group).

mostly unknown. In this setting, we found that cell migration and integrin upregulation induced by leptin were attenuated by OB-Rb knockdown. Upon leptin binding, OB-Rb could activate JAK2, which in turn phosphorylated tyrosine residues in the receptor tails, leading to the recruitment and activation of STAT-3 (28). The leptin receptor, through the activation of JAK2, was also able to downregulate SOCS3 proteins and stimulate the downstream signaling pathway $(13,29)$. Herein, we used the OB-Rb shRNA to determine its role and found that it inhibited leptin-induced migration and JAK2/STAT-3/ SOCS3 upregulation, indicating the possible involvement of $\mathrm{OB}-\mathrm{Rb}$ in leptin-induced cell growth and migration in GBC-SD cells.

Human MMPs, also known as collagenase, are a matrix metalloproteinase originally identified in breast carcinomas (30). Recent studies have revealed that this enzyme was also produced by a variety of malignant tumors (31). In all of the cases, the expression of MMPs was associated with 


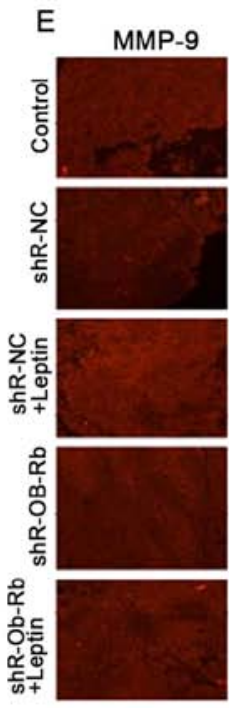

$\mathrm{H}$
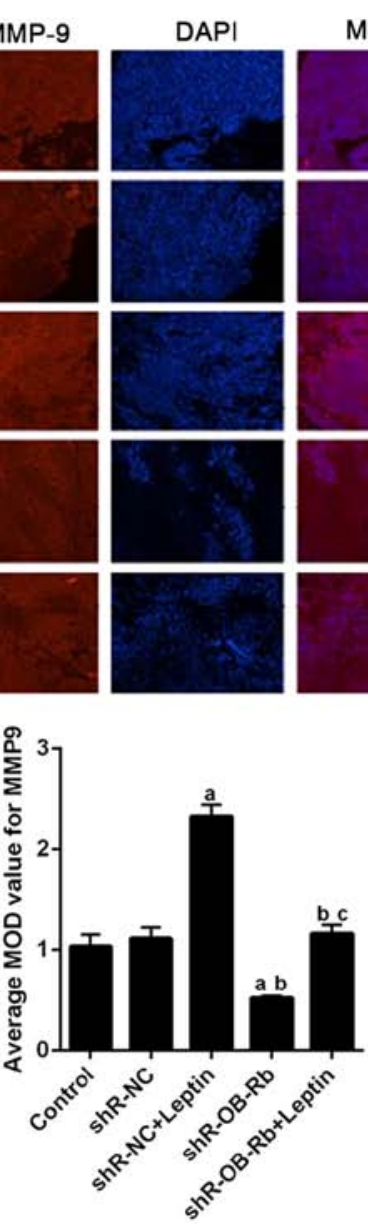
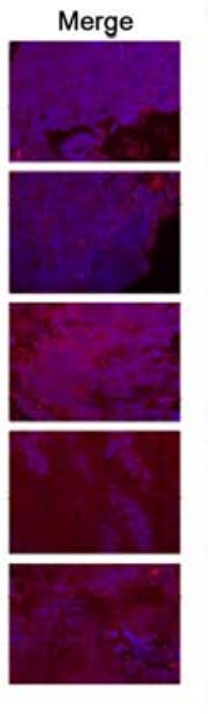
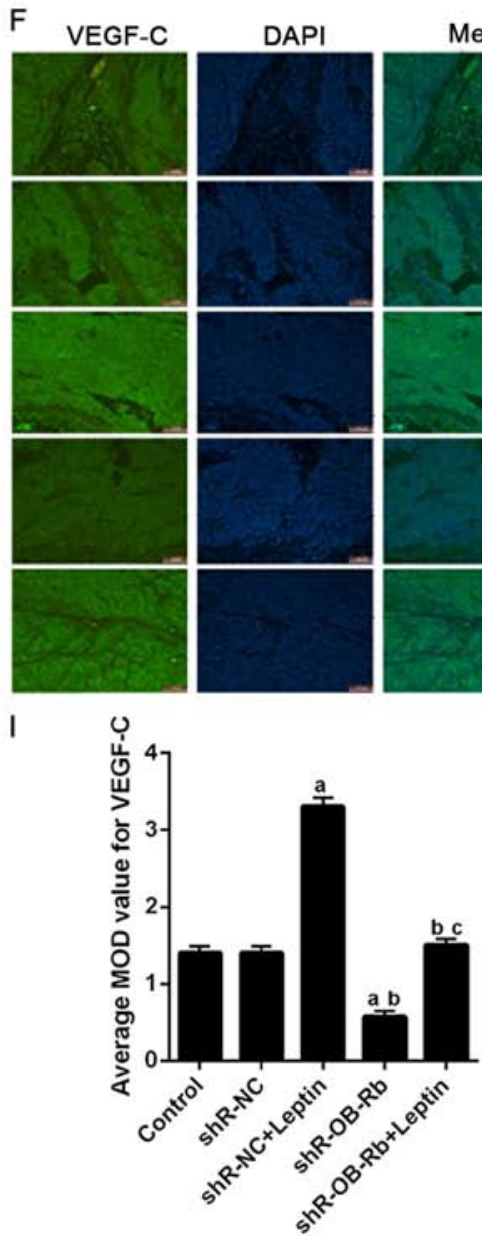
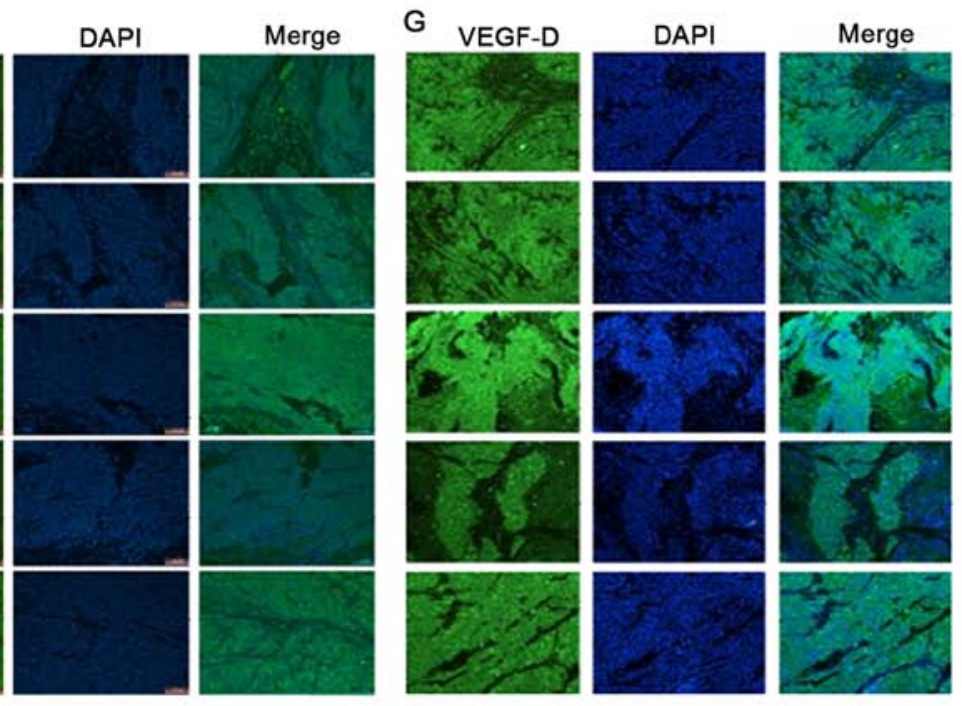

J

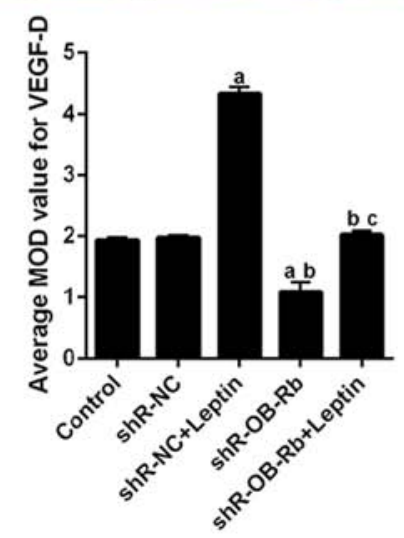

Figure 4. Continued. Leptin or OB-Rb regulates MMP3/9 and VEGF-C/D. The protein expression of MMP3/9 and VEGF-C/D were also confirmed by immunofluorescence (E-J) analysis and in leptin or shR-OB-Rb-transfected GBC-SD cells. These data represent the mean \pm SD of three independent experiments. Statistical analysis used two-tailed Student's t-test ( ${ }^{a} \mathrm{P}<0.05$ vs. shR-NC group; ${ }^{\mathrm{b}} \mathrm{P}<0.05$ vs. shR-NC $+\mathrm{Leptin}$ group; ${ }^{\mathrm{P}}<0.05$ vs. shR-OB-Rb group).

aggressive tumors. GBC is known to have a high potential for invasion and metastasis. In the present study, we compared the expression levels of MMP-3 and MMP-9 in GBC cells with and without leptin and/or OB-Rb shRNA treatment. We found MMP-3/9 was activated by treating with leptin, and downregulated by $\mathrm{OB}-\mathrm{Rb}$ interruption suggesting that leptin's regulation of MMPs is in a tissue-specific manner.

In addition, cell migration, and metastatic colonization must be successful with angiogenesis, which is essential for metastasized tumors in distant sites (32). Thus, we detected VEGF-C/D, which is the most important mediator of tumor angiogenesis, inducing formation of new blood vessels (33). Our study indicated that leptin could increase VEGF-C/D expression in vivo and in vitro. However, further research is necessary to clarify the mechanism underlying this process. Considering previous studies and the results described above, leptin and its receptor OB-Rb could be a potential therapeutic target for GBC.

In summary, our data showed that leptin and its receptor $\mathrm{OB}-\mathrm{Rb}$ may be implicate in growth and metastasis of gallbladder carcinoma, which may involve the regulation of MMPs and VEGF family through SOCS3/JAK2/STAT3 pathways. Regulation of leptin and its receptor OB-Rb could serve as a promising intervention strategy for gene therapy of gallbladder carcinoma.

\section{Acknowledgements}

This work is supported by grants from the Basic Research for Application Fund of Yunnan China (nos. 2012FB050 and 2011FZ124). The work is also funded by National Natural Science Foundation of China (83160360).

\section{References}

1. Dwivedi AN, Jain S and Dixit R: Gall bladder carcinoma: Aggressive malignancy with protean loco-regional and distant spread. World J Clin Cases 3: 231-244, 2015.

2. Boutros C, Gary M, Baldwin K and Somasundar P: Gallbladder cancer: Past, present and an uncertain future. Surg Oncol 21: e183-e191, 2012.

3. Caldow Pilgrim CH, Groeschl RT, Quebbeman EJ and Gamblin TC: Recent advances in systemic therapies and radiotherapy for gallbladder cancer. Surg Oncol 22: 61-67, 2013.

4. Siegel RL, Miller KD and Jemal A: Cancer statistics, 2015. CA Cancer J Clin 65: 5-29, 2015.

5. Halaas JL, Gajiwala KS, Maffei M, Cohen SL, Chait BT, Rabinowitz D, Lallone RL, Burley SK and Friedman JM: Weight-reducing effects of the plasma protein encoded by the obese gene. Science 269: 543-546, 1995.

6. Vona-Davis L and Rose DP: Adipokines as endocrine, paracrine, and autocrine factors in breast cancer risk and progression. Endocr Relat Cancer 14: 189-206, 2007.

7. Surmacz E: Obesity hormone leptin: A new target in breast cancer? Breast Cancer Res 9: 301, 2007. 
8. Fan Y, Gan Y, Shen Y, Cai X, Song Y, Zhao F, Yao M, Gu J and Tu H: Leptin signaling enhances cell invasion and promotes the metastasis of human pancreatic cancer via increasing MMP-13 production. Oncotarget 6: 16120-16134, 2015.

9. Dong Z, Xu X, Du L, Yang Y, Cheng H, Zhang X, Li Z, Wang L, Li J, Liu H, et al: Leptin-mediated regulation of MT1-MMP localization is KIF1B dependent and enhances gastric cancer cell invasion. Carcinogenesis 34: 974-983, 2013.

10. Kloek C, Haq AK, Dunn SL, Lavery HJ, Banks AS and Myers MG Jr: Regulation of Jak kinases by intracellular leptin receptor sequences. J Biol Chem 277: 41547-41555, 2002.

11. Livak KJ and Schmittgen TD: Analysis of relative gene expression data using real-time quantitative PCR and the 2(-Delta Delta C(T)) method. Methods 25: 402-408, 2001.

12. Barone I, Catalano S, Gelsomino L, Marsico S, Giordano C, Panza S, Bonofiglio D, Bossi G, Covington KR, Fuqua SA, et al: Leptin mediates tumor-stromal interactions that promote the invasive growth of breast cancer cells. Cancer Res 72: 1416-1427, 2012.

13. Frühbeck G: Intracellular signalling pathways activated by leptin. Biochem J 393: 7-20, 2006.

14. Yang $\mathrm{R}$ and Barouch LA: Leptin signaling and obesity: Cardiovascular consequences. Circ Res 101: 545-559, 2007.

15. Goel HL and Mercurio AM: VEGF targets the tumour cell. Nat Rev Cancer 13: 871-882, 2013.

16. Gong Y, Chippada-Venkata UD and Oh WK: Roles of matrix metalloproteinases and their natural inhibitors in prostate cancer progression. Cancers (Basel) 6: 1298-1327, 2014.

17. Garofalo C and Surmacz E: Leptin and cancer. J Cell Physiol 207: 12-22, 2006.

18. Saglam K, Aydur E, Yilmaz M and Göktas S: Leptin influences cellular differentiation and progression in prostate cancer. J Urol 169: 1308-1311, 2003

19. O'brien SN, Welter BH and Price TM: Presence of leptin in breast cell lines and breast tumors. Biochem Biophys Res Commun 259: 695-698, 1999.

20. Petridou E, Belechri M, Dessypris N, Koukoulomatis P, Diakomanolis E, Spanos E and Trichopoulos D: Leptin and body mass index in relation to endometrial cancer risk. Ann Nutr Metab 46: 147-151, 2002.

21. Saxena NK, Sharma D, Ding X, Lin S, Marra F, Merlin D and Anania FA: Concomitant activation of the JAK/STAT, PI3K/AKT, and ERK signaling is involved in leptin-mediated promotion of invasion and migration of hepatocellular carcinoma cells. Cancer Res 67: 2497-2507, 2007.
22. Bahceci M, Tuzcu A, Akkus M, Yaldiz M and Ozbay A: The effect of high-fat diet on the development of obesity and serum leptin level in rats. Eat Weight Disord 4: 128-132, 1999.

23. Calle EE, Rodriguez $\mathrm{C}$, Walker-Thurmond $\mathrm{K}$ and Thun $\mathrm{MJ}$ Overweight, obesity, and mortality from cancer in a prospectively studied cohort of U.S. adults. N Engl J Med 348: 1625-1638, 2003

24. Somasundar P, Riggs D, Jackson B, Vona-Davis L and McFadden DW: Leptin stimulates esophageal adenocarcinoma growth by nonapoptotic mechanisms. Am J Surg 186: 575-578, 2003.

25. Fava G, Alpini G, Rychlicki C, Saccomanno S, DeMorrow S, Trozzi L, Candelaresi C, Venter J, Di Sario A, Marzioni M, et al: Leptin enhances cholangiocarcinoma cell growth. Cancer Res 68: 6752-6761, 2008

26. Yang W-H, Liu S-C, Tsai C-H, Fong YC, Wang SJ, Chang YS and Tang CH: Leptin induces IL-6 expression through OBRl receptor signaling pathway in human synovial fibroblasts. PLoS One 8: e75551, 2013

27. Otvos L Jr and Surmacz E: Targeting the leptin receptor: A potential new mode of treatment for breast cancer. Expert Rev Anticancer Ther 11: 1147-1150, 2011.

28. Oh HK, Choi YS, Yang Y-I, Kim J-H, Leung PC and Choi J-H: Leptin receptor is induced in endometriosis and leptin stimulates the growth of endometriotic epithelial cells through the JAK2/STAT3 and ERK pathways. Mol Hum Reprod 19: 160-168, 2013.

29. Benomar Y, Roy AF, Aubourg A, Djiane J and Taouis M: Cross down-regulation of leptin and insulin receptor expression and signalling in a human neuronal cell line. Biochem J 388: 929-939, 2005.

30. Shuman Moss LA, Jensen-Taubman S and Stetler-Stevenson WG: Matrix metalloproteinases: Changing roles in tumor progression and metastasis. Am J Pathol 181: 1895-1899, 2012.

31. Deryugina EI and Quigley JP: Tumor angiogenesis: MMP-mediated induction of intravasation- and metastasissustaining neovasculature. Matrix Biol 44-46: 94-112, 2015.

32. Valastyan S and Weinberg RA: Tumor metastasis: Molecular insights and evolving paradigms. Cell 147: 275-292, 2011.

33. Hoeben A, Landuyt B, Highley MS, Wildiers H, Van Oosterom AT and De Bruijn EA: Vascular endothelial growth factor and angiogenesis. Pharmacol Rev 56: 549-580, 2004. 